\title{
C) HitsTón
}

\section{"Queremos vingança”. O afundamento de navios brasileiros pelo submarino alemão U-507 e as reações populares no Rio de Janeiro}

\author{
"We want revenge". The sinking of Brazilian ships by the German submarine U-507 and \\ the chain reaction in Rio de Janeiro
}

\section{Jorge Ferreira"}

Resumo: O afundamento de cinco navios brasileiros por submarino alemão, com centenas de mortes, repercutiu de maneira impactante na sociedade brasileira. Nos dias I8 e i9 de agosto de 1943, na cidade do Rio de Janeiro, na época capital da República, ocorreram manifestações de protestos, com passeatas e comícios. Homens e mulheres, trabalhadores e estudantes, exigiam que o governo brasileiro declarasse guerra à Alemanha.

Palavras-chave: Segunda Guerra Mundial; Brasil e a Segunda Guerra; Submarino U-507.

Abstract: The sinking of five Brazilian ships by a German submarine, causing hundreds of deaths, had a strong repercussion on the Brazilian society. On the $18^{\text {th }}$ and $19^{\text {th }}$ of August, 1942 in Rio de Janeiro by the time it was the national capital, there were protests filled with rallies. Men and women, workers and students, demanded that the Brazilian government declare war against Germany.

Keyworks: Second World War, Brasil and the Second World War; Submarine U-507

Nos anos 1930, debates ocorriam entre grupos políticos e militares que apoiavam o governo Vargas. Duas questões eram centrais: a implantação de uma usina siderúrgica, criando fundamentos para a industrialização do país, e o rearmamento do Exército demandado pela própria instituição militar. As armas e os equipamentos eram obsoletos e

\footnotetext{
"Professor Titular de História do Brasil da Universidade Federal Fluminense, Doutor em História Social pela Universidade de São Paulo e coordenador do grupo de pesquisa Brasil Republicano - Pesquisadores em História Cultural e Política (BR-PHCP/UFF). A pesquisa é financiada pelo CNPq.
} 
em pouca quantidade, faltavam munições, uniformes, caminhões e carros de transportes, sem contar com o despreparo de suas tropas (MOURA, I993 e BARROS, 20IO). Criar uma base industrial para o país e aparelhar o Exército eram objetivos mais imediatos do governo (SVARTMAN, 1996). A resistência do governo dos Estados Unidos em financiar a construção da usina siderúrgica foi vencida quando a empresa alemã Krupp demonstrou interesse no investimento (LOCHRERY, 2015, p. 78). Diferente, no entanto, era dotar o país de um exército equipado e bem treinado. Líderes políticos e militares norte-americanos não confiavam no governo Vargas o suficiente para isso.

Oportunidades surgiram com as rivalidades entre as grandes potências capitalistas. $\mathrm{Na}$ América Latina nessa época, Estados Unidos e Alemanha competiam abertamente. Segundo Gerson Moura, nos anos 1930 Vargas aproveitou “as melhores oportunidades criadas pela competição entre a Alemanha e os EUA no sentido de influenciar os rumos do Brasil" (MOURA, I993, p. I79). Ele qualifica a política externa brasileira na década de I930 de equidistância pragmática, nos planos comerciais, políticos e militares. Nas palavras de Antonio Pedro Tota, Vargas "procurava manter-se, no plano internacional, equidistante em relação tanto ao imperialismo mercantil ianque como ao imperialismo romanticista germânico" (TOTA, 2000, p. 27). O governo Vargas assinou contratos comerciais tanto com a Alemanha como com os Estados Unidos.

O objetivo do governo brasileiro era obter vantagens econômicas nas relações com potências rivais e em conflito. ${ }^{\mathrm{I}} \mathrm{O}$ Brasil tornou-se o maior parceiro comercial da Alemanha na América Latina. Da Itália fascista o governo Vargas adquiriu submarinos, pagando-os com a exportação de carne e produtos agrícolas. Comprou destróieres dos Estados Unidos e material bélico da Grã-Bretanha. Na avaliação de Lilia Schwarcz e Heloisa Starling, "Vargas via a neutralidade como uma estratégia de aproveitamento máximo das circunstâncias" (SCHWARCZ; STALING, 20I5, p. 384).

A eclosão da guerra obrigou o governo brasileiro a alterar sua política externa. No limite, Vargas teria que optar pelas forças Aliadas. Os Estados Unidos conseguiram fazer valer seus interesses junto aos países latino-americanos tanto na I Reunião dos Chanceleres Americanos, na cidade do Panamá, em setembro de 1939, quanto na Conferência de Havana, em junho de 1940. O resultado dos dois eventos foi que os países latino-americanos declararam sua neutralidade diante da guerra europeia e decidiram que o ataque militar a um país do continente seria considerado agressão a todos. A

\footnotetext{
${ }^{\mathrm{I}} \mathrm{O}$ grupo político que apoiava Vargas também formulava as diretrizes da política externa. Na interpretação de Paulo Fagundes Visentini, Getúlio Vargas "inaugurou um novo estilo, o da barganha nacionalista a serviço de um projeto nacional de modernização econômica e político-institucional" (VISENTINI, 2009, p. I2).
} 
neutralidade era do interesse do governo dos Estados Unidos, evitando que os países latino-americanos apoiassem o Eixo.

Contudo, após o ataque japonês à base militar norte-americana de Pearl Harbor, no Hawaii, em dezembro de I94I, o governo dos Estados Unidos convocou nova reunião de chanceleres de países da América Latina. A Conferência do Rio de Janeiro foi realizada em janeiro de 1942, um mês depois da investida japonesa. O representante norte-americano recomendou aos países da América Latina o rompimento de relações diplomáticas com Alemanha, Japão e Itália. A política de equidistância pragmática do governo brasileiro não poderia mais continuar (MOURA, I993, p. I83-I84). O Brasil seguiu a indicação e rompeu relações diplomáticas com os países do Eixo, no dia 28 de janeiro.

A decisão do governo Vargas significou o alinhamento brasileiro aos Estados Unidos, alterando as relações entre os dois países. Para o governo norte-americano, o Brasil passou a ser considerado aliado especial no continente americano (PINHEIRO, 2013, p. I53). O Exército brasileiro recebeu daquele país armas, munições, aviões, caminhões, entre outros equipamentos, conseguindo o almejado reaparelhamento. Um dos maiores objetivos do governo Vargas, a usina siderúrgica, começaria a ser construída entre Rio de Janeiro e São Paulo - na cidade de Volta Redonda. Em contrapartida, o governo brasileiro autorizou os militares norte-americanos a montarem bases no Nordeste do país e ocuparem a ilha de Fernando de Noronha.

Os brasileiros pagariam caro pela aliança política e militar com os Estados Unidos. Não demoraria para o governo nazista retaliar.

O artigo tem por objetivo conhecer os protestos populares no Rio de Janeiro, então capital da República, nos dias I8 e I9 de agosto de 1942, com as notícias dos afundamentos dos navios brasileiros por submarino alemão. O que houve na Capital Federal naqueles dois dias foi atípico, considerando-se que o país vivia sob regime autoritário, ainda durante a ditadura do Estado Novo. Milhares de pessoas invadiram as ruas expressando indignação e sentimento de revolta, e, ao mesmo tempo, exigindo do governo reações diante da agressão alemã.

\section{Primeiros navios brasileiros na alça de mira}

Desde que o governo brasileiro rompeu relações diplomáticas com os países do Eixo, navios mercantes brasileiros foram atacados por submarinos alemães e italianos no Caribe e na costa leste dos Estados Unidos. Dezenas desses submarinos estavam na região 
afundando navios mercantes norte-americanos e de outros países. O primeiro navio brasileiro torpedeado foi o Buarque, em I5 de fevereiro de 1942 , sem vítimas fatais. O segundo foi o Cabedelo, com 54 tripulantes. Não se sabe a data certa, presumindo-se que tenha sido entre I4 e 25 de fevereiro na região do Caribe. A seguir, em I8 de fevereiro, foi a vez do Olinda. Todos os tripulantes foram salvos por homens da Marinha dos Estados Unidos. No dia 7 de março, submarino alemão afundou o Arabutan. Um tripulante morreu no ataque. Os torpedeamentos de cargueiros brasileiros abarrotados de alimentos e matérias-primas para os Estados Unidos causavam indignação na população brasileira. A irritação, no entanto, transformou-se em revolta nas ruas com o afundamento do navio Cairu, em 8 de março. Estavam na embarcação 89 pessoas, entre passageiros e tripulantes. Deles, sobreviveram 36 (SANDER, 2007, p. 52-73).

Afundar navios mercantes era prática comum durante a guerra. Embarcações alemães também sofriam tais ataques. No Brasil, soavam intoleráveis o ataque aos navios e a morte de pessoas, entre outras razões porque o país não participava da guerra. Com o Cairu, a irritação social chegou ao limite, e populares tomaram as ruas do centro do Rio de Janeiro protestando - a primeira manifestação de que se tem notícia. Sob censura, a imprensa não teve como dar informações. Contudo, nota publicada na imprensa pela chefatura de polícia permite imaginar o que aconteceu:

\begin{abstract}
Ontem pela manhã um grupo de pessoas exaltadas percorreram as ruas mais centrais da cidade, depredando propriedades de súditos das nações do Eixo. As autoridades policiais, interessadas na manutenção da ordem pública, intervieram rapidamente, impedindo por meio suasórios que continuassem as depredações e que se praticassem violências de todo e em todo inconveniente e inoportuno. ${ }^{2}$
\end{abstract}

A chefatura de polícia admitiu a ocorrência de violentos protestos populares, cujos maiores alvos foram estabelecimentos comerciais de alemães, italianos e japoneses. $\mathrm{O}$ afundamento do Cairu provocou tumultos populares na cidade - afirma o historiador inglês Neill Locherey: "a polícia demorou para restaurar a ordem e decidiu intervir apenas como último recurso" (LOCHERY, 2015, p. 159).

Outros ataques se seguiram no mês de maio com a investida a diversos navios: o Parnaíba, com sete mortes; o Comandante Lira, com duas mortes; e o Gonçalves Dias, com seis mortes. Em junho, duas embarcações foram torpedeadas sem vítimas fatais, o Alegrete e o

\footnotetext{
${ }^{2}$ Diário de Notícias. Rio de Janeiro, 13 de março de 1942, $\mathrm{I}^{\mathrm{a}}$ página.
} 
Pedrinhas. Em julho afundaram o Tamandaré, com quatro vítimas fatais, o Barbacena, com seis, e o Piave com uma.

Os torpedeamentos eram noticiados na imprensa brasileira e causavam revolta na população, gerando sentimento de aversão à Alemanha nazista. O mais grave, no entanto, estaria por acontecer.

\section{O U-507 entra em ação}

O que ocorreu em agosto de 1942 foi diferente. Adolf Hitler estava especialmente irritado com o governo brasileiro. Motivos não faltavam: o rompimento de relações diplomáticas; a prisão de agentes de espionagem alemães; e os acordos militares com os Estados Unidos, com tropas militares daquele país sendo alocadas no nordeste brasileiro e o afundamento de submarino alemão por bombardeiro norte-americano cedido à Força Aérea Brasileira - FAB (SANDER, 2007, p. 173). O submarino alemão U-507 foi enviado para o litoral brasileiro. O comandante, o capitão de corverta Harro Schacht, recebeu ordens para atacar qualquer navio, com exceção de argentinos e chilenos.

No dia 15 de agosto, o navio Baependi partiu de Salvador rumo ao porto da cidade do Recife, levando mercadorias e passageiros. Utilizar navios como meio de transportes entre as cidades litorâneas do país era comum nessa época. Passavam poucos minutos das 19 horas quando dois torpedos foram lançados pelo U-507, atingindo o Baependi. Havia na embarcação 323 pessoas, entre tripulantes e passageiros. Destas, morreram 270.

As leis internacionais foram violadas. A indicação era para que o comandante disparasse o primeiro torpedo, esperasse que todos deixassem o navio em botes salva-vidas e somente depois disparasse o segundo torpedo. O objetivo era afundar o navio, preservando a vida de passageiros e tripulantes. Ao disparar os dois torpedos com intervalo de menos de um minuto, o comandante do submarino teve o intuito de matar todos dentro do navio. ${ }^{3}$

Duas horas depois, o U-507 disparou um torpedo contra o navio mercante Araraquara. A violência da explosão partiu a embarcação no meio, que afundou em cerca de cinco minutos. Das I46 pessoas a bordo, I3I morreram, entre passageiros e tripulantes, homens, mulheres e crianças. Horas mais tarde, às 4 horas e 5 minutos da manhã do dia I6, outro torpedo atingiu o navio Aníbal Benévolo. Entre passageiros e tripulantes, a

\footnotetext{
${ }^{3}$ Marcelo Monteiro teve acesso ao diário do capitão de corveta Harro Schacht. Havia problema na mira do U507. Anteriormente ele havia disparado dois torpedos contra o Baependi, mas os perdeu. Para evitar perder outros torpedos, disparou dois em intervalos curtos (ver MONTEIRO, 2003).
} 
embarcação levava I54 pessoas, das quais dezesseis crianças. Segundo anotações no diário de Harro Schacht, o navio afundou em 45 segundos. Conseguiram se salvar apenas quatro pessoas. No total, 150 morreram.

No dia I7, na entrada da Baía de Todos os Santos, às II horas, o U-507 disparou um torpedo contra o Itagiba. A maioria das I79 pessoas, entre passageiros e tripulantes, conseguiu se salvar, embora 36 tivessem morrido. Duas horas depois, o Arará também foi atacado e afundou muito rapidamente, em cerca de um minuto. Dos 35 tripulantes, 20 morreram.

Entre o início da noite do dia 15 e o início da tarde do dia I7, os torpedos do U-507 tiraram a vida de 607 brasileiros: 270 no Baependy, I3I no Araraquara, 150 no Aníbal Benévolo, 36 no Itagiba e 20 no Arará. As notícias dos torpedeamentos chegaram nas principais capitais do país no dia I8. A crueldade do comandante alemão repercutiu na sociedade brasileira com imenso sentimento de revolta. Não eram ataques a navios mercantes que trafegavam entre países com mercadorias. O que ocorrera foram ataques a navios de passageiros nas costas brasileiras que iam de uma cidade para outra levando passageiros e mercadorias. Nenhuma justificativa havia para os ataques. Homens, mulheres e crianças que viajavam em seu próprio país foram mortos de maneira cruel.

\section{As notícias dos jornais}

Na Capital Federal, Rio de Janeiro, os jornais deram as notícias no dia I8 de agosto de 1942. No Correio da Manhã, Costa Rego, redator-chefe do jornal, escreveu texto condenando energicamente os ataques e exigindo do governo represálias contra o governo alemão. Afinado com o sentimento de aversão ao nazismo que percorria a sociedade brasileira, ele incitou ao ódio o povo alemão:

até prova em contrário, todo alemão estabelecido no Brasil é um elemento invisível da vanguarda de assalto. (...) O alemão era ontem o inimigo tácito; é hoje o inimigo identificado. Cumpre ao Brasil não considerá-lo senão como inimigo, e aos brasileiros combatê-lo, em vez de admirá-lo. (...) A humanidade só viverá tranquilo quando enfim se convencer de que a vida nobre, digna, elevada, é incompatível com o alemão - com o alemão e não 
somente com o nazista, pois o mal, antes de ser nazista, é alemão, e só é nazista porque é alemão. ${ }^{4}$

A notícia foi tão chocante que os editorialistas do jornal A Noite também publicaram duras críticas à Alemanha nazista:

um governo e um povo, que cometem, ou permitem que em seu nome se cometam torpezas de tal natureza, revelam-se inadaptáveis à vida, num meio de cultura e progresso. (...) Que o povo brasileiro, tão duramente ferido nos seus mais sagrados sentimentos e nos seus mais legítimos interesses pelas hordas nazistas, esteja certo de que tais crimes não ficarão impunes, mas serão pagos olho por olho, dente por dente. ${ }^{5}$

A imprensa do Distrito Federal foi unânime na condenação ao ato de guerra. Não se pode alegar que se tratou de imposição do Departamento de Imprensa e Propaganda (DIP). Os textos traduziam muita indignação para serem tão somente impostos pelo governo. Lochery afirma, com razão, que, embora Vargas pudesse censurar a imprensa e até fechar jornais, "faltavam-lhe os meios práticos ou mesmo a vontade política para amordaçar por completo a imprensa" (LOCHERY, 2015, p. IO8) O afundamento dos navios brasileiros provocou revolta generalizada no país - expressada nas páginas dos jornais. No liberal Diário Carioca, por exemplo, artigo de Maurício de Medeiros concluiu que o ataque às embarcações somente comprova a existência da espionagem nazista no Brasil atuando de maneira ativa e eficiente. Policiais já tinham descoberto rádios-transmissores do Rio de Janeiro para Berlim. Como ignorar tais atividades? Como agir com benevolência? Medeiros foi enfático nas respostas: "cumpre que cada brasileiro se sinta com poder bastante para agir em apoio do governo, indicando às autoridades mais próximas tudo quanto lhe parecer suspeito". ${ }^{6}$

\section{Dia I8: o povo vai para as ruas}

A notícia do ataque aos cinco navios tomou de surpresa a população de inúmeras capitais de estados e municípios brasileiros. No Rio de Janeiro, segundo informações no jornal Diário de Notícias, foram os estudantes da Faculdade Nacional de Direito os

\footnotetext{
${ }^{4}$ Correio da Manhã. Rio de Janeiro, 20 de agosto de I942, p. 2.

${ }_{6}^{5}$ A Noite. Rio de Janeiro, $\mathrm{I} 8$ de agosto de $\mathrm{I} 942, \mathrm{I}^{\mathrm{a}}$ página.

${ }^{6}$ Diário Carioca. Rio de Janeiro, I9 de agosto de I942, p. 4.
} 
primeiros a saírem às ruas conclamando o povo a protestar. ${ }^{7}$ Mas nas ruas centrais da cidade destacava-se a presença não apenas de estudantes como também de trabalhadores e pessoas de classe média que tomaram conhecimento da tragédia pelos jornais logo ao amanhecer. Durante todo o dia, até altas horas da noite, a cidade foi tomada pelo "movimento popular de protesto", segundo Diários de Notícias. "Em toda a cidade", continua a reportagem, "elementos de todas as camadas sociais improvisaram demonstrações patrióticas, comícios e desfiles" em um "dos mais vibrantes movimentos de exaltação cívica registrados entre nós nos últimos tempos. ${ }^{8}$

Com o aumento do número de manifestantes nas ruas centrais, automóveis e ônibus foram obrigados a mudar de itinerário. Inicialmente muitos manifestantes se concentraram na Galeria Cruzeiro. Um senhor de idade avançada subiu em um caixote e falou para a multidão: “ao deixar a minha residência esta manhã, não dei certeza se voltaria. Mas aqui estou, vibrando como um jovem e clamando para que sejam vingados os nossos irmãos covardemente assassinados". 9

A multidão percorria ruas e avenidas carregando enormes bandeiras do Brasil, estandartes e retratos de Vargas. Alguns gritavam "viva o Brasil" e outros "morras ao nazismo". Io Pelas ruas podiam-se ouvir palavras de ordem como "hoje é dia de luto nacional" ou "Guerra! Guerra! Guerra!"II Era comum cartazes com a letra V de vitória, mas também havia outros com mensagens. Um deles dizia: "um inimigo covarde, que só age escondido entre as águas dos oceanos, merece o nosso castigo". ${ }^{2}$ No caso do comércio as portas eram fechadas à medida que aumentava o número de manifestantes nas ruas. Outros comerciantes encerraram as atividades a pedido dos populares. Na Cinelândia, manifestantes reconheceram o juiz de Direito Ribas Carneiro esperando um bonde. Ele voltou-se para a multidão e, com os dedos, fez o V, simbolizando a vitória. Seu gesto foi motivo para receber aplausos dos manifestantes. ${ }^{13}$ As passeatas e as manifestações não se limitaram ao centro da cidade, ocorrendo também nos subúrbios, como Jacarepaguá, Méier, Penha e Lins de Vasconcelos. ${ }^{I 4}$ Segundo Lochery, "de início, a polícia relutou em tomar uma atitude e permitiu que as multidões agissem sem muita interferência" (LOCHERY, 20I5, p. I86).

\footnotetext{
${ }^{7}$ Diário de Notícias. Rio de Janeiro, 19 de agosto, p. 5.

${ }^{8}$ Diário de Notícias. Rio de Janeiro, I9 de agosto de 1942, p. 3.

${ }^{9} \mathrm{O}$ Radical. Rio de Janeiro, 19 de agosto de 1942, p. 5.

${ }^{\text {Io }} O$ Jornal. Rio de Janeiro, I9 de agosto de $1942, \mathrm{I}^{\mathrm{a}}$ página.

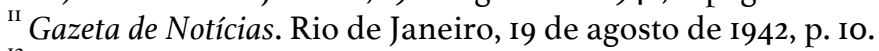

${ }^{12} \mathrm{O}$ Radical. Rio de Janeiro, 19 de agosto de I942, p. 5

${ }^{13}$ Gazeta de Notícias. Rio de Janeiro, I9 de agosto de 1942 , I ${ }^{\underline{a}}$ página.

${ }^{14}$ Diário de Notícias. Rio de Janeiro, 20 de agosto de 1942, Segunda Seção.
} 
Em pouco tempo podia-se ver a Bandeira Nacional hasteada em diversos prédios da avenida Rio Branco e das ruas do centro. Nos edifícios em que não havia a bandeira do país, estudantes e trabalhadores exigiam o hasteamento. Dezenas de comícios ocorriam ao mesmo tempo. Segundo informações da imprensa, vários deles foram realizados na Galeria Cruzeiro, nas ruas do Ouvidor e da Constituição, nas escadarias do Teatro Municipal, na praça José de Alencar, em frente ao prédio do Itamarati, como também em diversos bairros do subúrbio do Rio de Janeiro. Bandeiras do Brasil, segundo Diário de Notícias, "eram conduzidas pelo povo, ao longo da avenida Rio Branco, e o Hino Nacional, cantado entusiasticamente, a todo instante, de permeio com os brados de revolta contra os covardes inimigos da América". ${ }^{5}$

Jornais de tendência política alemã foram atacados pelos manifestantes. Gazeta de Notícias, por exemplo, a partir de 1938, tomou a defesa dos interesses da Alemanha, sobretudo com as generosas verbas publicitárias que a embaixada alemã investia no jornal. No ano seguinte, o jornal Meio-Dia, também recebendo apoio financeiro, passou a defender, com entusiasmo, o governo alemão. Investimentos inúteis, segundo Igor Gak, porque a população do Rio de Janeiro e as elites políticas e intelectuais da cidade desconfiavam das matérias publicadas, manifestando, inclusive, hostilidade aos dois jornais (GAK, 20I4, p. II9).

$\mathrm{Na}$ rua do Ouvidor, populares se aglomeraram na portaria do jornal Gazeta de Notícias. Por precaução, a redação já estava protegida por policiais. Como forma de protesto, eles exigiram que a Bandeira Nacional, hasteada no mastro do prédio do jornal, fosse retirada. As pessoas na redação obedeceram, e a polícia reforçou o cordão de isolamento para que as dependências do jornal não fossem invadidas. A seguir, a multidão seguiu pela rua do Ouvidor e avançou pelo Largo de São Francisco, alcançando a rua da Constituição, onde estava o prédio do jornal Meio-Dia. "A exaltação coletiva atingiu, nesse ponto, um grau inédito”, segundo Diário de Notícias. Também estavam na portaria do jornal vários policiais. Os manifestantes exigiram que a bandeira, ali içada, fosse entregue a eles. Após receberem o estandarte, levaram-no ao Palácio do Itamarati. Mais tarde, retornaram à sede do Meio-Dia e se depararam com homens do jornal tentando hastear outra bandeira. Os ânimos ficaram exaltados. Os revoltosos não admitiam que a insígnia do país, símbolo caro naquele momento, estivesse nas mãos de pessoas simpáticas aos seus inimigos. Não

\footnotetext{
${ }^{15}$ Diário de Notícias. Rio de Janeiro, I9 de agosto, de I942, p. 3.
} 
eram dignos de portá-la. Com o aumento da revolta popular, um homem da Polícia Especial retirou a bandeira do mastro. ${ }^{16}$

A Bandeira Nacional era carregada por muitos manifestantes e reverenciada naquele momento como símbolo do país que chorava seus mortos. O respeito ao estandarte era o respeito aos que morreram no mar. Por isso entendemos que, nas ruas, os manifestantes exigiam que, diante da bandeira, os homens tirassem o chapéu. Os que não faziam recebiam o aviso: “tem dono, tire o chapéu!" Segundo a imprensa, em frente à Associação dos Empregados no Comércio, um homem de nacionalidade alemã recusou-se a tirar o chapéu. Somente a intervenção policial evitou que ele sofresse agressões físicas. $\mathrm{Na}$ avenida Rio Branco, a multidão parou diante da casa comercial Hasenelever, de propriedade de alemães, e exigiu que a Bandeira Nacional fosse hasteada na entrada da loja - no que foram atendidos. Contudo, ainda na avenida Rio Branco, do alto de um prédio, alguém jogou um balde de água nos manifestantes. No edifício funcionava a Companhia Azzicurasioni Generali Italiana. A multidão invadiu o prédio em busca do homem que jogou água. Não o encontrando, destruíram o escritório da empresa. ${ }^{17}$

A revolta e a indignação popular voltaram-se não apenas contra jornais prógermânicos, mas também contra pessoas e estabelecimentos comerciais. Qualquer sinal de apoio aos países do Eixo era motivo de ira popular, mesmo uma simples suspeita. $\mathrm{Na}$ avenida Rio Branco, muitos consideraram que a empresa aérea Condor era de capital alemão, motivo para depredações. Com muito custo, funcionários alegaram que a empresa era de capital nacional e que não havia motivos para as agressões. ${ }^{18} \mathrm{O}$ proprietário do bar Danúbio Azul, de nacionalidade alemã, insistiu em manter abertas as portas de seu estabelecimento na rua Mem de Sá, na Lapa. Segundo a imprensa, muitos alemães frequentavam o bar. Repentinamente uma multidão avançou sobre o estabelecimento exigindo seu fechamento. O proprietário esboçou reação, mas segundo notícia publicada no jornal $O$ Radical, ele sofreu "as consequências naturais desse seu gesto". ${ }^{19}$ Outros bares foram depredados, como o Rhenania, o Zepelim e o Berlim - atual Bar Lagoa. O Clube Germânia, na Praia do Flamengo, foi expropriado pelo governo federal e doado à União Nacional dos Estudantes (UNE) para que lhe servisse como sede. (SANDER, 2007, p. 202). No bairro da Urca, o bar Tabajara, de propriedade de casal alemão, teve as vidraças quebradas e o estrago não foi maior devido a ação policial.

\footnotetext{
${ }^{16}$ Diário de Notícias. Rio de Janeiro, I9 de agosto de I942, p. 3.

${ }^{17} \mathrm{O}$ Radical. Rio de Janeiro, 19 de agosto de 1942, p. 5.

${ }^{18}$ Diário de Notícias. Rio de Janeiro, I9 de agosto de I942, p. 4.

${ }^{19} \mathrm{O}$ Radical. Rio de Janeiro, I9 de agosto de I942, p. 2.
} 
Nos jornais, era comum relatos de insubordinação de trabalhadores. Em Madureira, o gerente da companhia de fiação Rio de Janeiro, Franklin Srank Rowland, de nacionalidade alemã, não obedeceu à determinação do prefeito de suspender as atividades comerciais e industriais, mantendo a fábrica aberta. Revoltados, populares deram início à depredação do prédio, sendo impedidos de continuarem por policiais. No Cortume Carioca, na hora do almoço, operários de nacionalidade alemã comemoraram o ataque aos navios. Os trabalhadores brasileiros foram até a gerência e exigiram a demissão dos alemães. ${ }^{20}$ No Hotel Glória, os garçons, em assembleia, tomaram a decisão de não trabalhar sob ordens de funcionários da administração. Era o caso do "maiter-hotel" e de seus ajudantes, dos chefes do bar e da recepção. Todos eles, afirmaram os garçons, festejaram quando souberam do afundamento dos navios brasileiros. Os garçons deliberaram que enquanto todos os simpatizantes do Eixo não fossem afastados do hotel, eles não trabalhariam. Contudo, foram dissuadidos pelo gerente do hotel, de nacionalidade portuguesa. Ele prometeu que a reivindicação seria atendida brevemente. Decisão similar foi tomada pelos operários da Fábrica Souza Cruz, na rua Conde de Bonfim. Enquanto os funcionários de nacionalidade alemã não fossem demitidos, eles não voltariam ao trabalho. Para evitar a greve, o gerente da fábrica demitiu todos os operários alemães. Segundo a reportagem do Diário Carioca, os operários da fábrica de cigarros disseram que os trabalhadores "alemães, a cada torpedeamento de um dos nossos navios, reuniam-se para comemorar entre risadas o fato, num verdadeiro desrespeito ao nosso sentimento patriótico". ${ }^{21}$

O sentimento de antipatia ao nazismo que circulava na sociedade brasileira antes dos ataques do U-507 foi redimensionado. A antipatia tornou-se aversão. Os mais prejudicados foram pessoas de nacionalidade alemã e italiana que viviam no país. As expressões "alemão" e "nazista" tomaram o mesmo significado naqueles dias. Na praia de Jurujuba, em Niterói, a polícia prendeu um homem de nacionalidade alemã que se banhava nu na praia. Como não tinha documentos, os policiais queriam saber como ele entrou em território brasileiro. Esse foi o motivo para sua detenção. ${ }^{22}$ Diário de Notícias relata a ocorrência de vários incidentes, como depredações e tentativas de incendiar residência de estrangeiros. Na rua Lins de Vasconcelos, um apartamento de família de tchecoslovacos foi invadido e assaltado. O texto jornalístico condenou o episódio. Tratava-

\footnotetext{
${ }^{20}$ Diário de Notícias. Rio de Janeiro, I9 de agosto de I942, p. 4.

${ }^{2 \mathrm{I}}$ Diário Carioca. Rio de Janeiro, 2I de agosto de 1942 , $\mathrm{I}^{\mathrm{a}}$ página.

${ }^{22}$ Diário da Noite. Rio de Janeiro, I9 de agosto de I942, p. 8.
} 
se de "elementos desordeiros" que fizeram o "jogo dos inimigos". A polícia entrou em ação e, segundo o jornal, "diversos desses indivíduos foram presos". ${ }^{23}$

O sentimento de vingança tomou o país. A indignação popular era imensa, e pessoas inocentes, sobretudo italianos e alemães, sofreram arbitrariedades e violências seja de populares, seja da polícia. Em muitos casos, a população aliou-se às forças policiais na caçada aos "quinta-colunas". Segundo Marcelo Monteiro, "o simples fato de ter um sobrenome alemão ou italiano" era motivo "suficiente para praticamente condenar um imigrante à execração". Ainda segundo Monteiro, o mesmo ocorria, talvez de maneira ainda mais grave, "nos casos de brasileiros natos" que demonstravam simpatia pelo Eixo. Como alemães e italianos, os "traidores da pátria" eram detidos, "na maior parte das vezes por populares" (MONTEIRO, 2003, p. 2II). Não casualmente italianos que integravam a Organização Antifascista do Rio de Janeiro emitiram nota denunciando a "tirania de Mussolini", condenando os ataques aos navios brasileiros e se solidarizando com as famílias enlutadas. Segundo a nota:

hoje, como nunca, reiterando nossa solidariedade, ante o grande desastre sofrido pelo país que nos acolheu de braços abertos, retomamos nossa marcha para a vitória das Democracias, certos de cumprir um imperioso dever em prol de nossa Pátria adotiva e também em favor do povo italiano, que vive a mercê dum tirano vil e sem escrúpulos. ${ }^{24}$

Ainda não eram II horas e todo o comércio e a indústria da cidade estavam fechados por determinação do prefeito Henrique Dodsworth. Ele também suspendeu as atividades escolares em sinal de luto pelas mortes dos brasileiros. Ainda na parte da manhã, os manifestantes se concentraram na Cinelândia e, nas escadas do Teatro Municipal, realizaram comício. Falaram estudantes, operários, mulheres, jornalistas, entre outros. ${ }^{25} \mathrm{De}$ acordo com Roberto Sander, I2 mil jovens, liderados pelo presidente da UNE, Luís Pinheiro Paes Leme, participaram do comício (SANDER, 2007, p. 202).

Por aquela hora, podia-se ver o chefe de Polícia do Distrito Federal Alcides Etchegoyen andando pela avenida Rio Branco. Ele foi indicado para o cargo no mês anterior, em julho, assumindo no lugar do temível Filinto Muller. A aliança do Brasil com os Estados Unidos foi decisiva para a mudança. Quando Etchegoyen era identificado nas

\footnotetext{
${ }^{23}$ Diário de Notícias. Rio de Janeiro, 20 de agosto de 1942, Segunda Seção.

${ }^{24}$ Diário da Noite. Rio de Janeiro, 20 de agosto de I942, p. 3.

${ }^{25} \mathrm{O}$ Radical. Rio de Janeiro, I9 de agosto de I942, p. 5.
} 
ruas recebia aplausos do povo. Ao chegar na Cinelândia, deparou-se com o comício realizado nas escadarias do Teatro Municipal. Caminhando por entre a multidão, Etchegoyen pediu a todos que mantivessem a calma e confiassem nas medidas que o governo estava tomando. Segundo o Diário de Notícias, naquele dia, "a vida da cidade ficou, assim, gravitando totalmente em torno dos acontecimentos que empolgavam a opinião pública, crescendo a todo momento o número de manifestantes que percorriam as principais ruas do centro". ${ }^{26}$

Muitos se concentraram em frente à embaixada dos Estados Unidos, na avenida Presidente Wilson. Os manifestantes cantaram o Hino Nacional e deram "vivas" aos presidentes Vargas e Roosevelt. A seguir, rumaram para a Casa D’Italia, onde funcionava, naquele momento, a Faculdade de Filosofia do Ministério da Educação e o Serviço de Estatística do Ministério da Justiça. Os revoltosos entraram no prédio e tentaram retirar duas grandes placas de bronze que estavam nas paredes do prédio. Um funcionário que ali trabalhava tentou impedir a depredação, sendo confundido com um defensor do Eixo e, por isso, agredido fisicamente. Os manifestantes mudaram o nome da praça em frente à Casa D’Italia. A Praça Itália foi renomeada de Baependi - referência a um dos navios torpedeados. ${ }^{27}$

Os marítimos, categoria profissional que se sentia mais atingida pelo ataque alemão, concentraram-se na avenida Rio Branco. Após conversações com outros manifestantes, sobretudo estudantes e trabalhadores, tomaram a decisão de falar diretamente com o presidente Vargas no Palácio do Catete. Ao passarem pela Cinelândia, identificaram o prefeito Henrique Dodsworth, motivo para entusiásticos aplausos. Chegando à avenida Beira-Mar, a multidão alcançou o Palácio do Catete. Funcionários do Palácio avisaram que o presidente estava na residência oficial, no Palácio Guanabara, mas que manifestara o desejo de receber os manifestantes. Pela rua do Catete chegaram ao Largo do Machado. Entre a rua Paissandu e o Palácio Guanabara, a multidão gritava palavras de ordem, como "viva o Brasil", "morras ao nazismo" e "morras ao quintacolunistas". As autoridades policiais decidiram garantir a passeata. O delegado Frota Aguiar e o próprio chefe de polícia, Alcides Etchegoyen, tomaram a frente da manifestação, assegurando a marcha e a integridade dos manifestantes. Ambos também foram aplaudidos pela multidão. Vargas determinou que os portões do Palácio fossem abertos. Ao entrar nos jardins, o grupo

\footnotetext{
${ }^{26}$ Diário de Notícias. Rio de Janeiro, I9 de agosto de I942, p. 3.

${ }^{27}$ Diário de Notícias. Rio de Janeiro, I9 de agosto de I942, p. 3; e O Radical. Rio de Janeiro, I9 de agosto de I942, p. 5 .
} 
começou a cantar o Hino Nacional, seguido de mais de cinco minutos de aplausos. ${ }^{28}$ Cerca de I8 mil pessoas, entre trabalhadores, estudantes e marítimos, participaram da manifestação (MONTEIRO, 20I3, p. I67).

Uma comissão de estudantes, entre moças e rapazes, foi recebida por militares que assessoravam o presidente. Os jovens manifestaram o desejo de ver pessoalmente Vargas e levar a ele a solidariedade do povo e dos próprios estudantes. Queriam também protestar contra a agressão alemã. Os portões do amplo saguão de entrada do Palácio foram abertos. $^{29}$ Uma comissão de marítimos que contava com sobreviventes do Arabutã, do Cairu, do Tamandaré e do Olinda também foi recebida por assessores do presidente da República. O líder dos marítimos, Aldebram Beltrão, falou rapidamente. Segundo relato nos jornais, ele condenou o ato de pirataria alemão, salientando "a solidariedade dos marítimos em torno do presidente da República" e afirmando ainda que "o Brasil podia contar, sempre, em todas as horas, com a coragem, com o devotamento e com o patriotismo dos homens do mar”. A seguir, a menina Ana Maria, filha do comandante do Baependi, João Soares da Silva, morto devido ao torpedeamento do navio, chorando, entregou uma Bandeira Nacional ao assessor governamental, pedindo-lhe que esta fosse entregue a Vargas, em sua homenagem..$^{30}$

Vargas chegou ao salão ao lado da mulher, senhora Darcy Vargas, da filha Alzira, e acompanhado do chefe da polícia e de outros militares. Muito aplaudido, ele aparentava estar emocionado ao ouvir o discurso de um estudante da Faculdade de Direito. O jovem afirmou que todos ali estavam para protestar contra a agressão sofrida e levar ao presidente a solidariedade dos estudantes e do povo. A agressão, alegou o estudante, não ficaria impune. A seguir, Vargas tomou a palavra, falando pausadamente e de improviso. Disse compreender o sentimento de revolta e indignação diante de um "ato de pirataria". Não havia motivos para aquele ataque e por isso o ato não ficaria impune. Uma medida a ser tomada era que os navios pertencentes aos países agressores fossem incorporados ao patrimônio nacional como pagamento aos prejuízos causados. Além disso, os bens dos súditos do Eixo adquiridos no Brasil seriam expropriados. Os espiões que facilitaram a localização das embarcações para o ato hostil do submarino seriam presos e punidos. Ao final, o presidente pediu a todos que retornassem aos seus lares "com a consciência tranquila e de cabeça alta, levando aquela bandeira que era uma flâmula de esperança e que deveria significar, para todos, que as ocorrências contra as quais se protestava não

\footnotetext{
${ }^{28}$ O Jornal. Rio de Janeiro, I9 de agosto de 2016 , $\mathrm{I}^{\mathrm{a}}$ página.

${ }^{29}$ Gazeta de Notícias. Rio de Janeiro, I9 de agosto de 1942, p. I e Io.

${ }^{30}$ Diário de Notícias. Rio de Janeiro, I9 de agosto de I942, p. 4.
} 
podiam afetar o coração do Brasil” ${ }^{31}$ A seguir, todos se retiraram cantando o Hino Nacional e gritando palavras de ordem.

O mesmo grupo de populares que tomou a Bandeira Nacional do jornal Meio-Dia mais tarde dirigiu-se para a avenida Marechal Floriano rumo ao Palácio Itamarati. Chegaram às 15 horas e exigiram a presença do ministro das Relações Exteriores, Osvaldo Aranha. Ele demorou uma hora e meia para aparecer na sacada do Palácio acompanhado do embaixador do Chile. Recebeu dos manifestantes aplausos demorados. Após cantarem o Hino Nacional, o grupo que representava os manifestantes entregou a ele a Bandeira Nacional..$^{32}$ É curioso, nesse sentido, o valor dado ao panteão. Como símbolo que representava o próprio país, ele não poderia ficar em mãos inimigas, assim como no caso do jornal Meio-Dia. Seu lugar era no Palácio do Itamarati, em particular com um representante do governo. Mas também não com qualquer autoridade pública. Tratava-se do chanceler Osvaldo Aranha, homem defensor da aliança entre Brasil e Estados Unidos contra os países do Eixo. Quando se trata de motins populares, nada é casual. Um dos manifestantes discursou em seguida, insistindo que "a selvageria dos ataques não diminuía a coragem nem abatia o ânimo dos brasileiros" que, confiantes, esperavam providências do governo. $\mathrm{O}$ chanceler discursou longamente para a multidão. Em certo momento, ele foi enfático:

\begin{abstract}
agora, meus patrícios, não nos devemos mais iludir. A situação criada pela Alemanha e pelos seus aliados, praticando atos de beligerância, bárbaros e desumanos contra a nossa navegação pacífica e costeira, impõe uma reação à altura dos processos e dos métodos por eles empregados contra oficiais, soldados, mulheres, crianças e navios brasileiros. ${ }^{33}$
\end{abstract}

Outro imenso grupo de manifestantes caminhou em direção ao Palácio Duque de Caxias, sede do Ministério da Guerra. O objetivo era falar diretamente com o ministro Eurico Gaspar Dutra. A multidão chegou ao prédio do ministério às 17 horas exigindo a presença do ministro da Guerra. Dutra atendeu aos reclamos populares e apareceu na sacada do primeiro andar acompanhado de outros militares. Um dos manifestantes, o sr. José Alves de Morais, discursou. Em certo momento, mostrou pedaços da placa de bronze arrancada da Casa D’Itália. Ele a ofereceu ao ministro da Guerra para que ele fundisse o

\footnotetext{
${ }^{31}$ Gazeta de Notícias. Rio de Janeiro, I9 de agosto de I942, p. I e Io.

${ }^{32}$ Diário de Notícias. Rio de Janeiro, I9 de agosto de I942, p. 3 e Segunda Seção.

${ }^{33} \mathrm{O}$ Radical. I9 de agosto de I942, p. 4.
} 
material e o transformasse em balas "destinadas a participar da luta contra as potências agressoras". O protesto popular naquele dia estava repleto de simbolismos. Outro orador, o professor José Schiavo, elogiou as Forças Armadas alegando que o povo confiava nelas, certo de que "saberão vingar as afrontas recebidas pelo Brasil". O general Eurico Dutra não falou, mesmo diante da multidão. Discursou por ele o tenente-coronel João Pinto Paca. Segundo suas palavras: "manda o s. ex. que reitere ao povo estar o Exército vigilante e ativo". Paca foi interrompido por palmas vindas da multidão. Continuando, o oficial concluiu:

pode o povo confiar no Exército, tanto quanto o Exército com ele se irmana na segurança e defesa do patriotismo moral e material do nosso Brasil. Nesta hora de graves apreensões e maiores responsabilidades, Exército e Povo se confundem dentro da ordem, pela ordem e para o Brasil.

Novas palmas foram ouvidas. Dando-se por satisfeita, a multidão retirou-se para outras ruas, continuando o protesto. ${ }^{34}$

Os manifestantes, naquele dia, foram ao encontro de três autoridades públicas: o presidente da República, o ministro das Relações Exteriores e o ministro da Guerra. Nada houve de inocente nas escolhas. Somente os três poderiam tomar alguma decisão sobre o afundamento dos navios e propor iniciativas de retaliação à Alemanha. O presidente e os ministros receberam os manifestantes, mas não lhes deram respostas naquele momento. $\mathrm{E}$ seria muito difícil tomar qualquer decisão naquele dia. Mas as manifestações exigiram do presidente e dos dois ministros algum tipo de resposta - e vale lembrar, durante a ditadura do Estado Novo.

O povo protestou nas ruas. E como se portou a polícia? Não há notícias de repressão policial na imprensa. É verdade que os meios de comunicação estavam sob censura. Mas os jornais relatam que o povo tomou as ruas, organizou comícios, realizou passeatas e exigiu satisfação de três autoridades públicas. O tom das manifestações era de revolta e indignação contra a agressão nazista e, ao mesmo tempo, de apoio ao governo. Sendo assim, seria contraproducente qualquer atitude repressiva naquele momento. Outra indicação para a mudança no comportamento policial foi que o truculento chefe de polícia Felino Muller havia sido substituído no cargo pelo tenente-coronel Alcides Etchgoyen.

\footnotetext{
${ }^{34}$ Diário de Notícias. 19 de agosto de 1942, p. 5.
} 
Contudo, é sempre difícil para o historiador trabalhar com fontes sob censura, caso da imprensa na época. Apesar das limitações, brechas podem ser encontradas para revelar aspectos dos conflitos daquele dia. Segundo relato em Diário de Notícias, durante a caminhada da multidão do centro da cidade até o Palácio Guanabara para falar com Vargas, ocorreram incidentes entre populares e a polícia. Dois homens saíram machucados no conflito: o estivador Antonio Ferreira Filho, de 82 anos, e José Souto, de 26. Contudo, o delegado de polícia Frota Aguiar interveio imediatamente, suspendendo pessoalmente “quaisquer entraves de parte da polícia ao grande cortejo". Logo a seguir, o próprio chefe de polícia Alcides Etchegoyen orientou os líderes da passeata sobre o melhor caminho para chegar ao Palácio Guanabara. ${ }^{35}$ Portanto, podemos supor que ocorreram conflitos entre populares e policiais, mas sendo sustados pelas intervenções das autoridades da área de segurança pública.

No início da noite, na Cinelândia, estudantes organizaram um grande comício. O número de participantes é desencontrado. Diário de Notícias avaliou em io mil pessoas, Diário da Noite em 20 mil, enquanto Gazeta de Notícias em 30 mil..$^{36} \mathrm{O}$ comício foi convocado pela UNE e divulgado pela rádio Tupi. ${ }^{37}$ Às 20 horas começou o evento. O primeiro a falar foi o presidente da UNE, Paes Leme, que manifestou revolta contra os atentados do Eixo, acentuando, segundo relato do jornal, a "repulsa aos agressores". ${ }^{8}$ Falaram diversos oradores. Ao final do comício, Paes Leme subiu no último degrau da escada do Teatro Municipal com uma bandeira com o símbolo da suástica nazista e a queimou. A seguir, milhares de pessoas cantaram o Hino Nacional.

Mas como Paes Leme teve acesso a uma bandeira com a suástica? Ele a recebera de duas mulheres, uma delas moradora de um prédio no bairro de Santa Tereza. Ela se sentiu incomodada com uma festa no apartamento ao lado, cujos moradores era um casal de alemães. Como o homem estava preso na Ilha das Flores por atividades de espionagem a serviço do Eixo, era estranho o som de pessoas rindo e cantando no apartamento vizinho. A mulher foi investigar. Quem abriu a porta foi a vizinha alemã. Não foi difícil avistar garrafas de espumantes e três homens, todos de nacionalidade alemã, que brindavam. $\mathrm{O}$ mais surpreendente foi constatar que a mesa estava forrada com uma bandeira da suástica. Chocada, ela saiu do prédio e procurou uma amiga, conhecida violinista no Rio de Janeiro. A música custou a acreditar, preferindo conferir a veracidade da informação. Rapidamente

\footnotetext{
${ }^{35}$ Diário de Notícias. Rio de Janeiro, I9 de agosto de I942, p. I e 2.

${ }^{36}$ Diário de Notícias. Rio de Janeiro, 19 de agosto de I942, p. 5; Diário da Noite. Rio de Janeiro, I9 de agosto de I942, I ${ }^{\text {a }}$ página; e Gazeta de Notícias. Rio de Janeiro, I9 de agosto de I942, p. II.

${ }^{37}$ Diário da Noite. Rio de Janeiro, I9 de agosto de $1942, \mathrm{I}^{\mathrm{a}}$ página.

${ }^{38}$ Diário de Notícias. Rio de Janeiro, 19 de agosto de I942, p. 5.
} 
as duas chegaram ao apartamento da alemã. Para surpresa da violinista, de fato, havia garrafas de espumantes na mesa sobre a bandeira da suástica. Embora a alemã alegasse que nada estava fazendo de mal, que se tratava de "uma festa íntima", a violinista exigiu que a bandeira lhe fosse entregue. Houve resistência inicial, logo abandonada com a ameaça de chamar a polícia. De posse da bandeira, as duas mulheres levaram-na à redação Diário da Noite. Os redatores do jornal sugeriram que a insígnia fosse levada ao comício que ocorria na Cinelândia e entregue ao presidente da UNE, Paes Leme. Foi o que elas fizeram. Segundo texto do jornal,

a queima da bandeira, que foi feita pelo acadêmico Paes Leme, presidente da União Nacional dos Estudantes, constituiu a nota máxima do grande meeting fazendo a multidão irromper em ruidosos aplausos, ao mesmo tempo que dirigia apupos a Hitler e seus asseclas. Foi imensa a satisfação da massa ao ver o fogo devorar a bandeira vermelha com a cruz suástica. ${ }^{39}$

Ao final do comício, os manifestantes decidiram novamente falar com Vargas. O chefe de polícia, Alcides Etchegoyen, tentou dissuadi-los, alegando a hora avançada e a necessidade de o presidente descansar. $^{4^{0}} \mathrm{~A}$ multidão não lhe deu ouvidos. Todos caminharam para o Palácio Guanabara. Foram recebidos pelo ministro da Justiça Marcondes Filho, pela senhora Darcy Vargas, pelo interventor Amaral Peixoto e pelos ministros de Estado. O presidente da UNE conversou com as autoridades e, a seguir, falou ao povo. De fato, o chefe de polícia tinha razão. O horário estava avançado e o presidente estava em seus aposentos, mas este havia designado o ministro da Justiça para receber os manifestantes e agradecer-lhes a homenagem. Marcondes Filho fez breve discurso. Segundo suas palavras, o povo poderia contar com a solidariedade do presidente da República e que "todos poderiam regressar tranquilos, na certeza de que a soberania nacional seria defendida, a todo custo pelo chefe de governo e que, mais do que nunca, o povo podia contar com a ação enérgica e justa do presidente da República". ${ }^{4 \mathrm{I}}$

\footnotetext{
${ }^{39}$ Diário da Noite. Rio de Janeiro, I9 de agosto de I942, p. 3 e 5.

${ }^{40}$ Gazeta de Notícias. Rio de Janeiro, I9 de agosto de 1942 , p. II. Vargas não estava bem. No dia I $^{\mathrm{o}}$ de maio, na ida ao estádio de São Januário, seu motorista tentou desviar o automóvel de outro que avançou o sinal na rua Silveira Martins. A batida frontal com um poste resultou em sérios problemas para Vargas. Ele fraturou o osso de uma das mãos, o maxilar inferior e o fêmur em região próxima a outra fratura que sofrera nove anos antes. Durante três meses ficou imobilizada em uma cama (NETO, 2013, p. 407-408).

${ }^{41}$ Diário de Notícias. Rio de Janeiro, I9 de agosto de I942, p. 2.
} 


\section{Dia 19: o povo ainda nas ruas}

No dia seguinte, I9 de agosto, praticamente todos os governos de países latinoamericanos emitiram notas oficiais solidarizando-se com o Brasil. Os embaixadores do México e dos Estados Unidos no Brasil apoiaram o povo brasileiro. ${ }^{42}$ Apenas dois governos não se manifestaram: o do Chile e o da Argentina, únicos países latino-americanos que não romperam relações diplomáticas com o Eixo.

O dia 19, no entanto, amanheceu com um comunicado do chefe de polícia do Distrito Federal, Alcides Etchegoyen. O texto divulgado pela Agência Nacional determinava que, por medida de segurança pública, estava "proibido todo e qualquer comício em logradouro público, sem a prévia licença da polícia”. Mais ainda, alegando garantir a tranquilidade pública e a defesa da população, cuja excitação estava sendo "explorada por pessoas de intuitos inconfessáveis", a chefatura de polícia determinou que bares e botequins encerrariam suas atividades às 20 horas. As diversões públicas deveriam terminar às 22 horas. A população deveria se recolher em seus lares até as 23 horas, com exceção de trabalhadores que necessitassem permanecer em suas funções além desse horário, tendo, no entanto, justificativa para isso. ${ }^{43} \mathrm{Na}$ interpretação de Lochery, as proibições foram motivadas pelo medo das autoridades de segurança pública de que os ataques contra indivíduos e empresas de origem italiana e alemã fugissem do controle. "As autoridades", afirma Lochery, "ainda lutavam para restaurar a ordem no país” (LOCHERY, 20I5, p. I88). Atitude inútil porque, naquele dia, o toque de recolher determinado pelo chefe de polícia foi ignorado pela população do Distrito Federal.

Durante todo o dia o povo permaneceu nas ruas. As passeatas e os comícios continuaram pelo centro da cidade. Na Galeria Cruzeiro, um orador gritou para a multidão: "é preciso responder com uma atitude concreta às agressões de Hitler. E o que queremos?” A resposta foi ouvida em coro por todos: “guerra ao Eixo! Guerra ao Eixo!" Em certo momento começou uma confusão entre a multidão. Segundo versões, simpatizantes da Alemanha nazista teriam provocado os manifestantes. A polícia interveio e, por equívoco, prendeu um rapaz que protestava contra o Eixo. A multidão reagiu em defesa do manifestante. Um tenente da Polícia Militar pediu serenidade a todos e tomou a decisão de libertar o rapaz. Palmas e gritos foram ouvidos e muitas palavras de ordem foram pronunciadas, como "viva o Brasil”, “viva a Polícia Militar” e “abaixo a quinta-coluna!”44 Às

\footnotetext{
${ }^{42} \mathrm{O}$ Radical. Rio de Janeiro, 20 de agosto de I942, p. 4.

${ }^{43}$ Diário de Notícias. Rio de Janeiro, 20 de agosto de I942, p. 3.

${ }^{44} \mathrm{O}$ Radical. Rio de Janeiro, 20 de agosto de 1942, p. 2.
} 
II horas estudantes reuniram-se no Diretório Central dos Estudantes da Universidade do Brasil e constituíram comissão com representação de todos os diretórios acadêmicos das faculdades do Rio de Janeiro e da Faculdade de Direito de Niterói. O objetivo da comissão era coordenar as manifestações contra a Alemanha. ${ }^{45}$

No início da tarde, milhares de marítimos, funcionários das empresas Lloyd Nacional e Costeira, participaram de passeata pelas ruas do centro da cidade. A seguir, foram para o Palácio Guanabara. No caminho, cantavam o Hino Nacional e portavam bandeiras do país. Às I6 horas chegaram ao Palácio. O presidente Vargas não pode recebêlos, mas uma delegação de marítimos foi recepcionada por assessores presidenciais. ${ }^{46}$ Ao deixar o Palácio, um dos trabalhadores que participou da comissão, o marítimo Arnaldo Ferreira da Silva, falou à multidão: "voltamos confiantes. Nós da Marinha Mercante brasileira não tememos a morte. Sou um simples operário, mas como brasileiro, e em nome dos meus companheiros, não admito que os nipo-nazifascistas continuem ultrajando a honra da minha Pátria”. ${ }^{47}$ Os marítimos retornaram ao centro da cidade cantando o Hino Nacional e carregando bandeiras do Brasil, dos Estados Unidos, da Inglaterra do Loide Brasileiro. Palavras de ordem eram ouvidas: "alerta Brasil", "confiamos no nosso chefe da nação", "abaixo o nipo-nazifascismo", "abaixo os traidores do Brasil”, "nós queremos guerra ao Eixo". Ao final da tarde, a passeata dos marítimos se dispersou e todos se juntaram à multidão que tomava o centro da cidade. ${ }^{48}$

Ao final do dia, multidão composta majoritariamente por estudantes concentrou-se na Praia Vermelha, no bairro da Urca. Tendo à frente os estudantes de Medicina, às I8 horas partiram novamente em passeata para o Palácio Guanabara cantando o Hino Nacional. Foram recebidos por assessores militares da presidência da República, e uma delegação foi conduzida para dentro do Palácio. Inicialmente, foram recebidos pelo general Manuel do Nascimento Vargas, pai do presidente da República. Com idade avançada, o velho gaúcho afirmou aos estudantes: "tenho vivido muito. Tenho assistido aos mais variados e surpreendentes acontecimentos. Nunca, entretanto, vi a nossa mocidade mais ciosa de seus deveres e mais unida em torno de um mesmo ideal pátrio". ${ }^{49}$ A seguir, Vargas recebeu a delegação de estudantes em seu gabinete. O estudante Eugenio Calvet comentou sobre o comício realizado anteriormente e anunciou ao presidente a disposição

\footnotetext{
${ }^{45} \mathrm{O}$ Radical. Rio de Janeiro, 20 de agosto de I942, p. 2.

${ }^{46}$ Diário de Notícias. Rio de Janeiro, 20 de agosto de I942, p. 4.

${ }^{47} \mathrm{O}$ Radical. Rio de Janeiro, 20 de agosto de 1942, p. 8.

${ }^{48} \mathrm{O}$ Radical. Rio de Janeiro, 20 de agosto de I942, p. 8.

${ }^{49}$ Diário de Notícias. Rio de Janeiro, 20 de agosto de I942, p. 3.
} 
dos estudantes de organizarem um batalhão de acadêmicos, como ocorreu em I880 na luta pela implantação da República. A seguir, ele discursou e, em certo momento, afirmou:

somos moços, somos fortes e somos conscientes e ao serviço do Brasil nos colocamos para o que for preciso, certo de que essa é a única atitude a tomar frente aos atos de desenfreada pirataria praticada por esse conluio de assassinos internacionais. O sangue do generoso e nobre povo brasileiro, derramado sem provocação, está clamando vingança. Estruge de todas as camadas da população o clamor da revolta. ${ }^{50}$

Vargas respondeu ao grupo de estudantes elogiando a conduta altiva e serena dos jovens, irmanados no ideal de grandeza e dignidade do Brasil.

Os estudantes da Faculdade Nacional de Direito da Universidade do Brasil realizaram comício à parte. A iniciativa do evento foi do Diretório Acadêmico. O comício foi realizado em frente ao prédio da Faculdade, próximo à Praça da República. Discursaram professores e alunos, bem como integrantes de escolas secundárias, como o Colégio Pedro II e o Curso Lafayette. Pedro Calmon, diretor da Faculdade Nacional de Direito, foi o último a se pronunciar. A tônica foi a repulsa ao ataque alemão. Em passeata, também foram até o Palácio Guanabara, onde foram recebidos pessoalmente pelo presidente Getúlio Vargas. $^{5 \mathrm{I}}$

A indignação popular continuava a se manifestar contra qualquer pessoa que demonstrasse apoio à Alemanha ou mesmo indiferença diante da tragédia. No dia 19, na parte da noite, multidão se concentrou em frente ao Teatro Municipal para participar do comício. Muitos que caminhavam para a Cinelândia, ao passaram pelo Palace Hotel, viram um homem que aparentava ser estrangeiro fazer gesto de desprezo à Bandeira Nacional, carregada por um dos manifestantes. Alguns populares avançaram sobre ele exigindo explicações. O homem, vendo-se acuado, sacou um punhal e ameaçou a todos, entrando, a seguir, no hotel. Pouco adiantou. Cerca de quinhentas pessoas entraram no saguão do Palace, exigindo sua prisão. A Polícia Especial chegou rapidamente, evitando o linchamento. Da sacada do quarto do estrangeiro, um homem da Polícia Especial mostrou o punhal para a multidão. O homem foi preso e preservado da fúria popular. ${ }^{52}$

\footnotetext{
${ }^{50} \mathrm{O}$ Jornal. Rio de Janeiro, 20 de agosto de 1942 , I ${ }^{\mathrm{a}}$ página.

${ }^{51}$ Diário de Notícias. Rio de Janeiro, 20 de agosto de I942, p. 6.

${ }^{52} \mathrm{O}$ Jornal. Rio de Janeiro, 20 de agosto, p. 5.
} 
$\mathrm{O}$ ataque do U-507 provocou manifestações de rua, notas de repúdio e demonstrações de pesar pelas vítimas expressas por várias instituições da sociedade, entre elas o Conselho Federal da Ordem dos Advogados do Brasil, o Liceu Literário Português, o Instituto Brasileiro de Cultura, a Sociedade dos Amigos de Alberto Torres, a Diretoria do Clube dos Advogados, o Grande Oriente do Brasil e o Diretório Acadêmico da Faculdade de Medicina do Pará. Organizações empresariais também manifestaram sua contrariedade com o ataque alemão, como a Bolsa de Valores do Rio de Janeiro e o Sindicato dos Lojistas. Clubes de Futebol expressaram solidariedade às vítimas, como o Botafogo Futebol Clube e o América Futebol Clube..$^{53}$ Manifestaram pesar o Tijuca Tênis Clube, o Grupo de Regatas Gragoatá, o Centro Recreativo de Braz de Pina, o Clube de São Cristóvão, a Associação Atlética Portuguesa, entre outros. ${ }^{54}$ A consternação pelas mortes dos brasileiros mobilizou a sociedade - particularmente os clubes de futebol. O Departamento de Imprensa Esportiva da Associação Brasileira de Imprensa (ABI) decidiu que no jogo entre Flamengo e Botafogo, o qual seria realizado no dia 23, haveria uma solenidade. Todos os jogadores, o juiz e os seus auxiliares, bem como os técnicos entrariam enlutados em campo, desfilando com a Bandeira Nacional. Na frente deles, iriam os escoteiros do Flamengo em passo lento. A seguir, haveria um minuto de silêncio em homenagem às vítimas. Por fim, uma banda militar executaria o Hino Nacional..$^{55}$

No Rio de Janeiro, os protestos populares parecem ter se limitado aos dias I8 e i9 de agosto. A imprensa noticiou apenas uma única manifestação popular no dia 20. Representantes de vários sindicatos dos marítimos reuniram-se na Praça Mauá com o objetivo de levar a Vargas "a solidariedade da classe”, na expressão utilizada por Gazeta de Notícias. Carregando cartazes, bandeiras do Brasil e pavilhões de seus sindicatos, os mais de 8 mil marítimos foram em passeata até o Palácio Guanabara falar com o presidente. Alguns sobreviventes dos navios afundados e familiares de desaparecidos na tragédia também participaram do ato público. ${ }^{56}$ Ao tomar as dependências do Palácio, Vargas, acompanhado da esposa e de ministros, ouviu o discurso do presidente da Federação Nacional dos Marítimos, Aldebram Beltrão. Ele manifestou solidariedade e apoio ao presidente e protestou contra os "atos de barbarismo" e "selvageria sistematizada, indigna da civilização" de que foram vítimas marítimos e passageiros dos navios torpedeados. Vargas discursou em seguida. Em resposta ao grave momento, o governo articulou ação conjunta

\footnotetext{
${ }^{53}$ Diário de Notícias. Rio de Janeiro, 20 de agosto de I942, p. 4.

${ }^{54}$ Diário de Notícias. Rio de Janeiro, 22 de agosto de 1942, p. 3

${ }_{55}^{5}$ Diário de Notícias. Rio de Janeiro, 22 de agosto de I942, p. 3.

${ }^{56}$ Gazeta de Notícias. Rio de Janeiro, 2I de agosto de $1942, \mathrm{I}^{\mathrm{a}}$ página.
} 
entre as três Forças Armadas brasileiras e as dos Estados Unidos no sentido de proteger melhor os mares que banham o Brasil. "Quanto aos homens do mar", alegou Vargas, "prejudicados nos bens e as famílias dos que foram vitimados, podiam ter a segurança de que o governo não os deixaria ao abandono". ${ }^{57}$ Ao final, os marítimos retornaram pela rua Paissandu cantando o Hino Nacional, continuando a manifestação na Praia do Flamengo.

Sobre o dia 20, nada além da manifestação dos marítimos foi noticiada nos jornais. O movimento de protesto pode ter chegado ao seu limite. Mas a polícia nas ruas pode ter feito cumprir, com o devido rigor, a proibição do chefe de polícia a novas manifestações. Talvez a hipótese levantada por Neill Lochery deva ser considerada: após a declaração de guerra à Alemanha e à Itália, “a ira punitiva que dominara o Brasil deu lugar a uma perspectiva mais sóbria, à medida que a população refletia sobre as incertezas e os desafios que a nação enfrentaria." (LOCHERY, 2015, p. 190). Seja como for, a partir do dia 20 não há mais notícias de manifestações populares nas ruas. A partir daí, organizações sociais, como a UNE, assumiram o protagonismo da luta contra o nazismo.

As manifestações de revolta, sofrimento e clamor por vingança não se limitaram ao Rio de Janeiro. Comícios, passeatas e manifestações públicas com milhares de pessoas ocorreram em várias capitais, como Goiânia, Belo Horizonte, Natal, Porto Alegre, Florianópolis, São Paulo, Vitória, Aracaju, Salvador, João Pessoas, Fortaleza, Recife, Terezinha, Curitiba e Belém. Protestos também aconteceram em vários municípios do interior do país. ${ }^{58}$ A repercussão nacional dessas manifestações foi expressiva no Rio de Janeiro porque se tratava da capital da República, mas mobilizações populares foram organizadas praticamente em todos os estados.

No dia 22 de agosto, após reunião ministerial, Getúlio Vargas, mesmo contrariando os chefes militares, declarou guerra à Alemanha e à Itália.

\section{Bibliografia citada}

BARROS, Orlando de. A guerra dos artistas. Dois episódios de história brasileira durante a Segunda Guerra Mundial. Rio de Janeiro: E-papers, 2010.

\footnotetext{
${ }^{57}$ Gazeta de Notícias. Rio de Janeiro, 2I de agosto de I942, p. IO.

${ }^{58}$ Diário de Notícias. Rio de Janeiro, 20 de agosto de I942, p. 7 e 22 de agosto de 1942, p. 2; Gazeta de Notícias. Rio de Janeiro, 23 de agosto de I942, p. 5.
} 
GAK, Igor. "Informantes impaciais": propaganda, antisseminismo e guerra na imprensa carioca durante o governo Vargas (I933-1942). In: FERREIRA, Jorge. O Rio de Janeiro nos jornais. Ideologias, culturas políticas e conflitos sociais (I930-I945). Rio de Janeiro: 7 Letras/Faperj, 2014.

LOCHERY, Neill. Brasil. Os frutos da guerra. Rio de Janeiro: Intrínseca, 2015.

MONTEIRO, Marcelo. U-507. O submarino que afundou o Brasil na Segunda Guerra Mundial. Porto Alegre: Pubblicato Editora, 2013.

MOURA, Gerson. Neutralidade dependente: o caso do Brasil, 1939-4. Estudos Históricos. Rio de Janeiro: vol. 6, n. I2, I993.

NETO, Lira. Getúlio. Do governo provisório à ditadura do Estado Novo. São Paulo: Companhia das Letras, 2013.

PINEIRO, Letícia. O Brasil no mundo. In: GOMES, Angela de Casto (coord.). Olhando para dentro. 1930-I964. São Paulo: Objetiva Fundación Mapfre, 2013 (História do Brasil Nação: I808-20Io, direção de SCHWARCZ, Lilia M.)

SANDER, Roberto. O Brasil na mira de Hitler. A história do afundamento de navios brasileiros pelos nazistas. Rio de Janeiro: Objetiva, 2007.

SVARTMAN, Eduardo Munhoz. As orientações fundamentais da política externa do primeiro governo Vargas. Anos 9o. Revista do Programa de Pós-Graduação em História da UFRGS. Porto Alegre, n. 5, jul. 1996.

TOTA, Antonio Pedro. O imperialismo sedutor. A americanização do Brasil na época da Segunda Guerra. São Paulo: Companhia das Letras, 2000.

VISENTINI, Paulo Fagundes. Relações exteriores do Brasil II (I930-I964). O nacionalismo, da Era Vargas à Política Externa Independente. 2. ed. Petrópolis: Vozes, 2009.

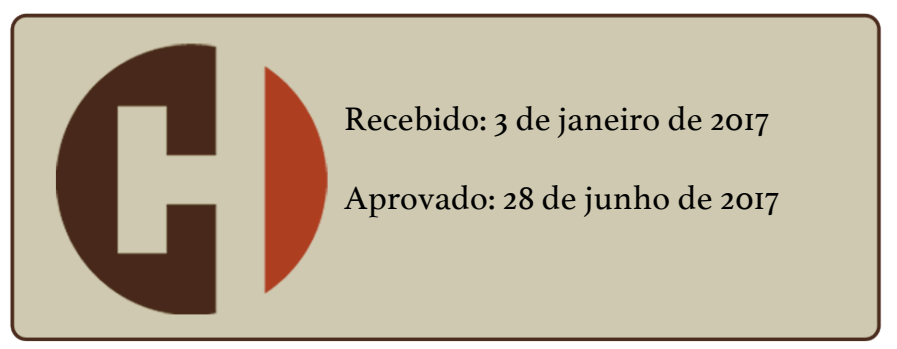

